\title{
Natural contents of heavy metals in soils of the southern Amazonas state, Brazil
}

\section{Teores naturais de metais pesados em solos da região sul do estado do Amazonas}

\author{
Rubia Darivanda da Silva Costa ${ }^{1 *}$; Pérsio Paula Neto ${ }^{2}$; Milton César Costa \\ Campos$^{3}$; Willian Barros do Nascimento ${ }^{4}$; Clístenes Williams Araújo do \\ Nascimento $^{5}$; Laércio Santos Silva ${ }^{6}$, José Mauricio da Cunha ${ }^{1}$
}

\begin{abstract}
Heavy metals occur naturally in the soil as a product of rock weathering and, are commonly associated with environmental pollution and toxicity to living beings. This association deserves much attention since some heavy metals, such as $\mathrm{Fe}, \mathrm{Mn}, \mathrm{Cu}, \mathrm{Zn}$, and $\mathrm{Ni}$, are essential to plants. Our attention should thus be drawn not only to the element itself, but also to its contents in the soil. This is because its occurrence and quantities are covariates of the geomorphic, geologic, pedologic, and anthropogenic diversity. In this context, the present study aimed to determine the natural contents of heavy metals in the soils of three physiographic regions of the south of Amazonas state, comparing them to natural contents in some other Brazilian soils. Twenty-four soil samples were collected in three physiographic regions (field/forest, animated relief, and flooded/non-flooded areas), in the superficial and subsurface horizons. The digestion of the samples was based on the EPA-3051A method and the determination by atomic absorption spectrophotometry (AAnalyst 800 Perkin Elmer). The results indicate a low potential of soils from the south of Amazonas in supplying heavy metals, which were found in the following decreasing order: $\mathrm{Ba}>\mathrm{Fe}>\mathrm{Cr}>\mathrm{Pb}>\mathrm{Zn}>\mathrm{Cu}>\mathrm{Mn}>\mathrm{Co}>\mathrm{Cd}$. The natural heavy metal contents vary depending on the type of soil, weathering level, and physiographic regions, and are similar or inferior to those observed in other regions of the country; with Neosols presenting the highest natural contents; and Cambisols, the lowest, for most of the metals evaluated.
\end{abstract}

Key words: Amazonas. Natural metal concentration. Micronutrients.

\section{Resumo}

Os metais pesados ocorrem naturalmente no solo como produto do intemperismo das rochas e, comumente, são associados com poluição ambiental e toxidade aos seres vivos. Essa relação merece atenção mais cautelosa, uma vez que alguns são essenciais às plantas como $\mathrm{Fe}, \mathrm{Mn}, \mathrm{Cu}, \mathrm{Zn}$ e Ni. Assim,

${ }^{1}$ M.e, Universidade Federal do Amazonas, UFAM, Instituto de Educação, Agricultura e Ambiente, IEAA, Humaitá, AM, Brasil. E-mail: rubia.dsc@gmail.com

${ }^{2}$ Eng $^{\text {o }}$ Ambiental, UFAM, Instituto de Educação, Agricultura e Ambiente, IEAA, Humaitá, AM, Brasil. E-mail: pv.apui@gmail. com

3 Prof. Dr., UFAM, Instituto de Educação, Agricultura e Ambiente, IEAA, Humaitá, AM, Brasil. E-mail: mcesarsolos@gmail.com

${ }^{4}$ Discente, Curso de Graduação em Engenharia Ambiental, UFAM, IEAA, Humaitá, AM, Brasil. E-mail: willianbarros18@gmail. com.

5 Prof. Dr., Universidade Federal Rural de Pernambuco, UFRPE, Departamento de Agronomia, Recife, PE, Brasil. E-mail: cwanascimento@yahoo.com

${ }^{6}$ M.e, Universidade Estadual Paulista Júlio de Mesquita Filho, UNESP, Faculdade de Ciências Agrárias e Veterinárias, FCAV, Departamento de Solos e Adubos, Jaboticabal, SP, Brasil. E-mail: laerciosantos18@gmail.com

* Author for correspondence 
a preocupação deve estar voltada não apenas ao elemento em si, mas aos teores desses no solo, visto que sua ocorrência e quantidade são covariativas da diversidade geomorfológica, geológica, pedológica e antrópica. Neste sentido, objetivou-se determinar os teores naturais dos metais pesados nos solos de três regiões fisiográficas da região Sul do Amazonas, comparando-os com os teores naturais de alguns solos do país. Foram coletadas 24 amostras de solo em três regiões fisiográficas (Campo/ Floresta, Relevo Movimentado e Várzea/Terra Firme), nos horizontes superficiais e subsuperficiais. A digestão das amostras baseou-se no método EPA-3051A, e a determinação com espectrofotometria de absorção atômica (AAnalyst 800 Perkin Elmer). Os resultados indicam baixo potencial dos solos do Sul do Amazonas em suprir metais pesados, sendo os maiores teores encontrados na seguinte ordem decrescente: $\mathrm{Ba}>\mathrm{Fe}>\mathrm{Cr}>\mathrm{Pb}>\mathrm{Zn}>\mathrm{Cu}>\mathrm{Mn}>\mathrm{Co}>\mathrm{Cd}$. Os teores naturais de metais pesados variam em função da classe de solo, grau de intemperismo e das regiões fisiográficas e são semelhantes ou inferiores aos observados em outras regiões do país; com Neossolos apresentando teores naturais mais elevados e, os Cambissolos, os mais baixos, para a maioria dos metais avaliados.

Palavras-chave: Amazonas. Concentração natural de metais. Micronutrientes.

\section{Introduction}

Heavy metals are a group of chemical elements naturally available in the environment as secondary components of rocks. Some of these elements are micronutrients ( $\mathrm{Fe}, \mathrm{Mn}, \mathrm{Cu}$, and $\mathrm{Zn})$ and others are especially beneficial to vegetal metabolism (Co, $\mathrm{Ni}$, and V) (BIONDI et al., 2011; MACEDO et al., 2012). However, the aforementioned elements can be harmful to fauna and flora when at high quantities (MECHI; SANCHES, 2010; KABATAPENDIAS, 2010), while others are considered by the Agency for Toxic Substances and Disease Registry as extremely hazardous $(\mathrm{Cd}, \mathrm{Cr}, \mathrm{Hg}$, and $\mathrm{Pb})$. Among them, $\mathrm{Cd}$ and $\mathrm{Pb}$ can be considered the most potentially dangerous elements, even in low concentrations, because of their carcinogenic or mutagenic characteristics (ATSDR, 2012).

In the absence of anthropogenic interventions, natural contents of heavy metals depend on soil source material, pedogenetic processes, and soil development level (SILVA et al., 2016). In general, under these conditions, these metals neither present a real threat to ecosystems nor to human health, as they occur in low concentrations (ATSDR, 2012). According to $\mathrm{Ng}$ et al. (2016), the soil is the main reservoir of $\mathrm{Cd}, \mathrm{Pb}, \mathrm{Mn}, \mathrm{Zn}, \mathrm{Cu}, \mathrm{Ba}, \mathrm{Fe}, \mathrm{Co}$ and $\mathrm{Cr}$, in which the bioavailability is controlled by biotic and abiotic factors. Thus, the potential of a soil in supplying plants with these elements can help botanical, ecological, and agricultural investigations, since certain species of plants can have a preference and have different tolerance levels for specific elements. (KABATA-PENDIAS, 2010). For this author, the accumulation of some heavy metals in plants occurs in the following sequence: $\mathrm{Ni}>\mathrm{Zn}>\mathrm{Pb}>\mathrm{Mn}>\mathrm{Cu}$; thus, being phyto-indicators of alterations in the natural heavy metals content in the soil.

From an ecological standpoint, the metal contents in soil, water and in plants allow us to make considerations as to the quality of the ecosystem (balance/environmental pollution) (MECHI; SANCHES, 2010). Thus, our knowledge regarding the origin and determination of natural metal contents in soil is of extreme importance to the establishment of environmental quality parameters of soils, which can guide the impact evaluation of human activities, since they are the main cause for increasing metal content in ecosystems (CONAMA, 2009).

In compliance with the national legislative organs, determining the natural content of the soil is necessary to frame it in the guiding parameters: Reference Guideline Values of Quality (RVQ), Variation Prevention (VP) and of Investigation (VI) (CONAMA, 2009). Through these numbers, it is possible to elaborate a legislation with monitoring norms and intervention measures, bearing in mind that determining natural concentrations allows us to differentiate the origin of these metals in the 
soil as natural or anthropic (SILVA et al., 2016; ALMEIDA JÚNIOR et al., 2016). Consequently, public authorities are capable of elaborating a specific legislation for monitoring and for legal interventions in line with the local reality (BAIZE; STERCKEMAN, 2001).

Only a few Brazilian states have had their natural heavy metal content defined, mainly because of their size, soil diversity, financial cost, and lack of professional (professional demand). São Paulo (CETESB, 2001), Espírito Santo (PAYE et al., 2010), Pernambuco (BIONDI et al., 2011a, b), Paraíba (ALMEIDA JÚNIOR et al., 2016), and Rio Grande do Norte (PRESTON et al., 2014) are prominent states compared to the others since they use this information for monitoring and for legal interventions befitting to the local reality. Thus, anthropic, agricultural, and urban actions able to increase heavy metal content levels could be avoided.

The state of Amazonas is still in need of this information, especially because of its global relevance and large territory, in addition to it possessing several types of soil each with peculiar characteristics, originated from different kinds of sediments. In this context, this study aimed to determine the contents of heavy metals in soils of three different physiographic regions of the southern part of Amazonas state, comparing it to the natural metal content of a few of the country's soils.

\section{Material and Methods}

This study was conducted in three physiographic regions of the southern Amazonas state: field-forest ecotone (F/F), animated relief (AR), and flooded/ non-flooded $(\mathrm{F} / \mathrm{N})$. The $\mathrm{F} / \mathrm{N}$ and $\mathrm{F} / \mathrm{F}$ areas are located in the city of Humaitá. The flooded areas are susceptible to seasonal floods, which occur near the banks of muddy rivers, and, during these periods, accumulate material from other origins (allochthonous). The non-flooded areas undergo no flooding conditions, so being formed by tertiary sediments. They are transitional areas between current alluvial and Holocene deposits, as well as sediments from the Solimões Formation, Upper Pleistocene, containing material prevenient from continental, fluvial, and lacustrine environmental depositions (BRASIL, 1978).

The sediments of this formation come from two sedimentation cycles: a) bottom sandy banks, which represent the pluvial and fluvial sedimentation; and b) upper clayey sediments, indicating lacustrine sediments. The other regions are located in the city of Manicoré, resting on Rondonianos Granites of Intrusive cratogenic origin (BRASIL, 1978). Their mineralogical composition is characterized by muscovite, biotite, adamellites, and granodiorites (CAMPOS, 2009).

The climate of the region is of the rainy tropical (A) and monsoon (Am) type, with a short dry period (ALVARES et al., 2014). The rainy season starts in October and ends in June and the average annual rainfall ranges from approximately 2,250 to 2,750 $\mathrm{mm}$. Average annual temperatures vary from $25^{\circ} \mathrm{C}$ to $27^{\circ} \mathrm{C}$ and average relative humidity of the air varies from 85 to $90 \%$.

From August to December, in the years of 2014 to 2016 , twelve representative soil profiles of the southern region of Amazonas were selected, i.e. four in each of the physiographic environments studied (Table 1). In each of these locations, two samples were collected using a steel auger at the 0.0-0.2 m and $0.8-1.00 \mathrm{~m}$ layers, totalizing 24 samples.

In the $0.0-0.2 \mathrm{~m}$ layer, ten subsamples were taken in a spacing of $3 \mathrm{~m}$ (each spaced out $3 \mathrm{~m}$ from the other), forming a compound sample, i.e. one subsample at the central point (mark), eight subsamples at the cardinal points $(\mathrm{E}, \mathrm{W}, \mathrm{N}, \mathrm{S}$, NE, NW, SW and SE), and one randomly chosen point. The homogeneity among the subsamples was considered for color, soil texture, topography, drainage, and vegetal cover (vegetation). At the 0.8 $1.00 \mathrm{~m}$ layer, three simple auger samplings were randomly done for the formation of a compound 
sample (Table 2). The physical, chemical and $\mathrm{Ki}$ and $\mathrm{Kr}$ weathering analyses were conducted as described by Embrapa (2011). Grain size was determined by pipette analysis using a 0.1 $\mathrm{N} \mathrm{NaOH}$ solution as a chemical dispersant and mechanical agitation in a high rotation device for 10 minutes. The fraction of clay was separated by sedimentation, the sand by sieving and silt was calculated by differentiation. The available organic carbon, $\mathrm{Ca}, \mathrm{Mg}, \mathrm{Al}, \mathrm{K}, \mathrm{P}$, and potential acidity $(\mathrm{H}$ $+\mathrm{Al}$ ) were determined (identified). Next, base sum (BS), cation exchange capacity (CEC), and base saturation (V \%) were calculated. The $\mathrm{pH}$ was potentiometrically determined using the 1:2.5 soil ratio in water (Table 2).

Table 1. Classes, location, physiographic regions, municipality and geographic coordinates of the studied soils in Southern Amazonas.

\begin{tabular}{|c|c|c|c|}
\hline Profile & Soil Classe & Municipality & Location \\
\hline \multicolumn{4}{|c|}{ Field/Forest } \\
\hline $\mathrm{P} 1$ & $\begin{array}{l}\text { CAMBISSOLO HÁPLICO Alítico plíntico } \\
\text { (Haplic Cambisol) }\end{array}$ & Humaitá-AM & $\begin{array}{l}07^{\circ} 30^{\prime} 22,6^{\prime \prime} \mathrm{S} \\
63^{\circ} 04^{\prime} 57,3^{\prime \prime} \mathrm{W}\end{array}$ \\
\hline $\mathrm{P} 2$ & GLEISSOLO HÁPLICO Alítico típico (Haplic Gleysol) & Humaitá-AM & $\begin{array}{l}07^{\circ} 30^{\prime} 16,3 \text { ”'S } \\
61^{\circ} 04^{\prime} 57,3^{\prime \prime} \mathrm{W}\end{array}$ \\
\hline P3 & $\begin{array}{l}\text { CAMBISSOLO HÁPLICO Alítico gleissólico } \\
\text { (Haplic Cambisol) }\end{array}$ & Humaitá-AM & $\begin{array}{l}07^{\circ} 29^{\prime} 59,0^{\prime \prime} \mathrm{S} \\
63^{\circ} 04^{\prime} 50,0^{\prime \prime} \mathrm{W}\end{array}$ \\
\hline P4 & $\begin{array}{l}\text { ARGISSOLO VERMELHO Alítico plíntico } \\
\text { (Red Argisol) }\end{array}$ & Humaitá-AM & $\begin{array}{l}07^{\circ} 29^{\prime} 55,1^{\prime \prime} \mathrm{S} \\
63^{\circ} 04^{\prime} 51,3^{\prime \prime} \mathrm{W} \\
\end{array}$ \\
\hline \multicolumn{4}{|c|}{ Animated Relief } \\
\hline P5 & $\begin{array}{l}\text { LATOSSOLO VERMELHO Distrófico típico } \\
\text { (Red Latosol) }\end{array}$ & Manicoré-AM & $\begin{array}{l}07^{\circ} 59^{\prime} 58,8^{\prime \prime} \mathrm{S} \\
61^{\circ} 34^{\prime} 27,7^{\prime \prime} \mathrm{W}\end{array}$ \\
\hline P6 & $\begin{array}{l}\text { ARGISSOLO VERMELHO-AMARELO Distrófico } \\
\text { abrúptico (Red - Yellow Argisol) }\end{array}$ & Manicoré-AM & $\begin{array}{l}07^{\circ} 59^{\prime} 51,6^{\prime \prime S} \mathrm{~S} \\
61^{\circ} 34^{\prime} 36,7^{\prime \prime} \mathrm{W}\end{array}$ \\
\hline P7 & $\begin{array}{l}\text { LATOSSOLO VERMELHO-AMARELO Eutrófico } \\
\text { típico (Red - Yellow Latosol) }\end{array}$ & Manicoré-AM & $\begin{array}{l}07^{\circ} 59^{\prime} 54,8^{\prime \prime} \mathrm{S} \\
61^{\circ} 34^{\prime} 46,4^{\prime \prime} \mathrm{W}\end{array}$ \\
\hline P8 & $\begin{array}{l}\text { LATOSSOLO VERMELHO-AMARELO Distrófico } \\
\text { típico (Red - Yellow Latosol) }\end{array}$ & Manicoré-AM & $\begin{array}{l}07^{\circ} 59^{\prime} 56,2 \text { '”S } \\
61^{\circ} 34^{\prime} 51,5^{\prime \prime} \mathrm{W}\end{array}$ \\
\hline \multicolumn{4}{|c|}{ Flooded/Non-Flooded } \\
\hline P9 & $\begin{array}{l}\text { LATOSSOLO AMARELO Distrófico plíntico } \\
\text { (Yellow Latosol) }\end{array}$ & Humaitá-AM & $\begin{array}{l}7^{\circ} 30^{\prime} 22^{\prime \prime} \mathrm{S} \\
63^{\circ} 011^{\prime} 15^{\prime} \mathrm{W}\end{array}$ \\
\hline $\mathrm{P} 10$ & $\begin{array}{l}\text { LATOSSOLO AMARELO Distrófico argissólico } \\
\text { (Yellow Latosol) }\end{array}$ & Humaitá-AM & $\begin{array}{l}7^{\circ} 30^{\prime} 22^{\prime \prime} \mathrm{S} \\
63^{\circ} 011^{\prime} 15^{\prime \prime} \mathrm{W}\end{array}$ \\
\hline P11 & $\begin{array}{l}\text { NEOSSOLO FLÚVICO Ta Eutrófico típico } \\
\text { (Fluvisol Neosol) }\end{array}$ & Humaitá-AM & $\begin{array}{l}7^{\circ} 30^{\prime} 22^{\prime \prime} \mathrm{S} \\
63^{\circ} 011^{\prime} 15^{\prime \prime} \mathrm{W}\end{array}$ \\
\hline $\mathrm{P} 12$ & $\begin{array}{l}\text { NEOSSOLO FLÚVICO Ta Eutrófico gleissólico } \\
\text { (Fluvisol Neosol) }\end{array}$ & Humaitá-AM & $\begin{array}{l}7^{\circ} 30 ’ 22^{\prime \prime} \mathrm{S} \\
63^{\circ} 011^{\prime} 15^{\prime \prime} \mathrm{W}\end{array}$ \\
\hline
\end{tabular}

Embrapa (2013).

After naturally drying, the samples were steel strainer containing 0.074-mm openings, as in weighed in nylon bags with 2-mm openings. Next, a portion of this material was collected and macerated in an agate mortar, and put through a stainlessABNT NBR $n^{\circ} 50$, (with a stainless steel mesh), to avoid contaminations. The digestion consisted of transferring $1 \mathrm{~g}$ of the samples to Teflon tubes, and 
adding $9 \mathrm{~mL}$ of nitric acid and $3 \mathrm{~mL}$ of hydrochloric acid. After verifying the tubes were hermetically sealed, they were kept in a microwave oven (Mars Express) for $13 \mathrm{~min}$, i.e. enough time for the equipment to reach $175^{\circ} \mathrm{C}$, as in the EPA $3051 \mathrm{~A}$ method (USEPA, 1998).

The acids used in the analyses were all of high purity (Merck PA). Dilutions and solutions were prepared with certified balloons and pipettes (NBR ISO/IEC), and in ultrapure water (Direct-Q 3 Millipore System). The extracts were filtered with quantitative paper filters - blue strip, slow filtration (Macherey Nagel ${ }^{\circledR}$ ). For glassware cleaning and decontamination, the instruments were maintained in a 5\% nitric acid solution for 24 hours, and dried with distilled water. The assessments of heavy metal contents were performed using atomic absorption spectrophotometry, flame photometry (air-acetylene). To evaluate the dependency between variables, principal component analysis was conducted, which is an exploratory multivariate technique to project the original information into a smaller set of latent variables, which are the eigenvectors constructed with the eigenvalues extracted from the covariance matrix, preserving the most relevant original information as possible (HAIR et al., 2005). After the standardization of the variables of the soil (heavy metals, chemical and physical), the number of components with eigenvalues above 1.00 were selected, as proposed by Kaiser (1958). Due to the exploratory character of the data, the descriptive statistics were performed (mean, median and deviation) and Pearson's linear correlations were established between the metals and the main soil attributes. All the statistical analyses were processed in the Statistica ${ }^{\circledR}$ software, version 7.0 (STATSOFT, 2008).

\section{Results and Discussion}

The variability of the heavy metal contents in the studied soils reflected the geologic and geomorphologic variations and the degree of pedogenesis of the southern region of Amazonas. The highest contents of heavy metals were observed in the Neosol profiles, situated in the $\mathrm{F} / \mathrm{N}$ environments; following this order from lowest to highest: $\mathrm{Ba}>\mathrm{Zn}>\mathrm{Fe}>\mathrm{Cu}>\mathrm{Pb}>\mathrm{Co}>\mathrm{Cd}$. While the highest content of $\mathrm{Mn}$ and $\mathrm{Cr}$ were observed in the Latosol and Argisol profiles of the AR. This is because these elements are concentrated in the form of oxides in more weathered soils (KABATAPENDIAS, 2010; SILVA et al., 2016) (Table 3, 4, and 5).

The average contents of $\mathrm{Cu}, \mathrm{Co}$ and $\mathrm{Cd}$ were higher in the Fluvisols (profiles 11 and 12) of the $\mathrm{C} / \mathrm{F}$ physiographic region (Table 3 ). Although the contents present a wide range of variations of $\mathrm{Cu}$ $\left(1.85-16.75 \mathrm{mg} \mathrm{kg}^{-1}\right)$ and Co $\left(0.03-8.68 \mathrm{mg} \mathrm{kg}^{-1}\right)$, no abrupt variations were observed within a single horizon, which draws attention to Haplic Gleysol (profile 2), because of its $\mathrm{Cu}$ contents, nearly five times higher than those from the surface. This indicates a strong influence of materials carried in from other environments, especially during the flooding period. 


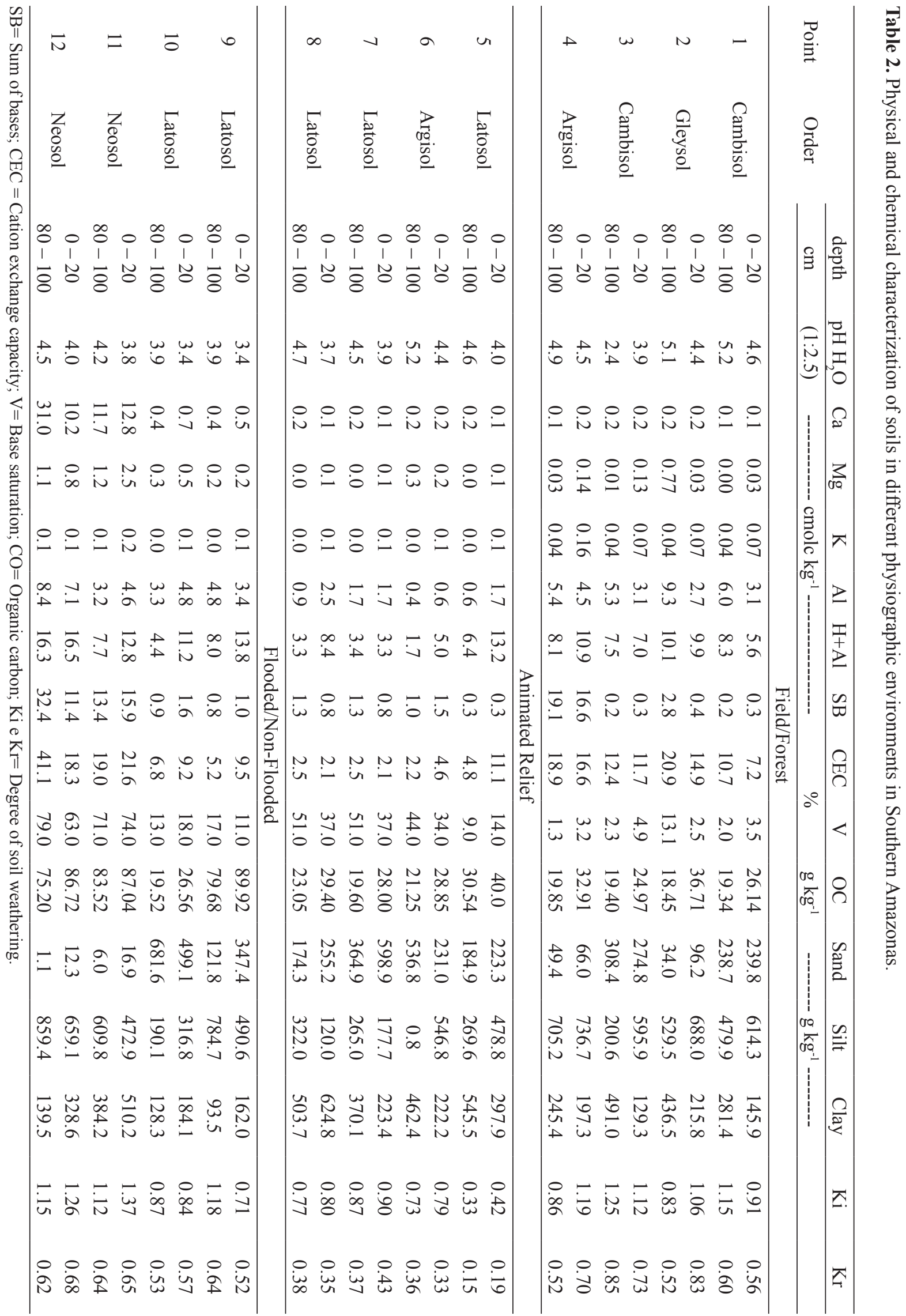


Table 3. Natural contents of $\mathrm{Cu}, \mathrm{Co}$ and $\mathrm{Cd}$ in the surface (sup.) and subsurface (sub.) horizon of the main classes of soils in Southern Amazonas.

\begin{tabular}{|c|c|c|c|c|c|c|}
\hline \multirow{2}{*}{ Profile } & \multicolumn{2}{|c|}{$\mathrm{Cu}$} & \multicolumn{2}{|c|}{ Co } & \multicolumn{2}{|c|}{$\mathrm{Cd}$} \\
\hline & Sup & Sub & Sup & Sub & Sup & Sub \\
\hline & \multicolumn{6}{|c|}{ 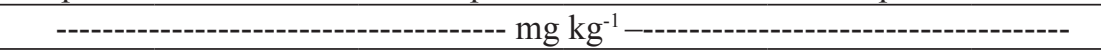 } \\
\hline & \multicolumn{6}{|c|}{ Field/Forest } \\
\hline 1 & 2.43 & 3.15 & 0.20 & 0.50 & $<\mathrm{Ld}$ & $<\mathrm{Ld}$ \\
\hline 2 & 16.75 & 3.43 & 0.28 & 0.88 & $<\mathrm{Ld}$ & $<\mathrm{Ld}$ \\
\hline 3 & 1.85 & 2.43 & 0.25 & 0.48 & $<\mathrm{Ld}$ & $<\mathrm{Ld}$ \\
\hline 4 & 3.00 & 3.18 & 0.45 & 0.48 & $<$ Ld & $<\mathrm{Ld}$ \\
\hline Average & 6.01 & 3.05 & 0.30 & 0.59 & 0.00 & 0.00 \\
\hline & \multicolumn{6}{|c|}{ Animated Relief } \\
\hline 5 & 6.63 & 8.85 & 0.10 & 0.03 & $<\mathrm{Ld}$ & $<\mathrm{Ld}$ \\
\hline 6 & 3.95 & 3.93 & 1.63 & 0.80 & $<\mathrm{Ld}$ & $<\mathrm{Ld}$ \\
\hline 7 & 3.78 & 5.85 & 1.85 & 2.03 & $<\mathrm{Ld}$ & $<\mathrm{Ld}$ \\
\hline 8 & 7.45 & 8.55 & 3.38 & 2.18 & $<\mathrm{Ld}$ & $<\mathrm{Ld}$ \\
\hline \multirow[t]{2}{*}{ Average } & 5.45 & 6.80 & 1.74 & 1.26 & 0.00 & 0.00 \\
\hline & \multicolumn{6}{|c|}{ Flooded/Non-Flooded } \\
\hline 9 & 3.10 & 3.48 & 0.05 & 0.85 & $<\mathrm{Ld}$ & $<\mathrm{Ld}$ \\
\hline 10 & 3.63 & 3.78 & 0.20 & 0.35 & $<\mathrm{Ld}$ & $<\mathrm{Ld}$ \\
\hline 11 & 21.40 & 19.63 & 6.48 & 6.38 & 0.23 & 0.05 \\
\hline 12 & 16.25 & 14.43 & 8.28 & 8.68 & 0.08 & 0.13 \\
\hline Average & 11.10 & 10.33 & 3.75 & 4.07 & 0.08 & 0.05 \\
\hline Median & 3.86 & 3.85 & 0.36 & 0.83 & 0.00 & 0.00 \\
\hline Average & 7.52 & 6.72 & 1.93 & 1.97 & 0.03 & 0.01 \\
\hline Standart deviation & 6.71 & 5.36 & 2.76 & 2.72 & 0.07 & 0.04 \\
\hline Asymmetry & 1.26 & 1.65 & 1.65 & 1.97 & 2.90 & 2.78 \\
\hline Kurtosis & 0.12 & 2.13 & 1.73 & 3.02 & 8.71 & 7.81 \\
\hline
\end{tabular}

$<$ Ld: Less than the detection limit. 
Table 4. Natural contents of Fe, Mn and $\mathrm{Zn}$ in the surface (sup.) and subsurface (sub.) horizon of the main classes of soils in Southern Amazonas.

\begin{tabular}{|c|c|c|c|c|c|c|}
\hline \multirow{2}{*}{ Profile } & \multicolumn{2}{|c|}{$\mathrm{Fe}$} & \multicolumn{2}{|c|}{$\mathrm{Mn}$} & \multicolumn{2}{|c|}{$\mathrm{Zn}$} \\
\hline & Sup & Sub & Sup & Sub & Sup & Sub \\
\hline & \multicolumn{2}{|c|}{-------- $\mathrm{g} \mathrm{kg}^{-1}$-------- } & \multicolumn{4}{|c|}{----------------------- $\mathrm{mg} \mathrm{kg}^{-1}$------------------- } \\
\hline & \multicolumn{6}{|c|}{ Field/Forest } \\
\hline 1 & 8.24 & 19.74 & 0.03 & 0.12 & 1.85 & 1.68 \\
\hline 2 & 3.37 & 20.45 & 0.13 & 0.06 & 8.05 & 2.80 \\
\hline 3 & 6.57 & 22.76 & 0.26 & 0.08 & 1.93 & 1.00 \\
\hline 4 & 8.62 & 7.15 & 0.37 & 0.04 & 5.70 & 2.28 \\
\hline \multirow[t]{2}{*}{ Average } & 6.70 & 17.53 & 0.20 & 0.08 & 4.38 & 1.94 \\
\hline & \multicolumn{6}{|c|}{ Animated Relief } \\
\hline 5 & 23.76 & 14.32 & 0.56 & 0.46 & 2.63 & 1.60 \\
\hline 6 & 16.67 & 12.45 & 7.20 & 1.76 & 1.55 & 0.35 \\
\hline 7 & 12.24 & 11.50 & 6.00 & 3.79 & 1.10 & 2.43 \\
\hline 8 & 16.07 & 25.96 & 7.55 & 6.73 & 2.95 & 2.63 \\
\hline \multirow[t]{2}{*}{ Average } & 17.19 & 16.06 & 5.33 & 3.19 & 2.06 & 1.75 \\
\hline & \multicolumn{6}{|c|}{ Flooded/Non-Flooded } \\
\hline 9 & 5.87 & 14.39 & 0.01 & 0.41 & 1.28 & $<\mathrm{Ld}$ \\
\hline 10 & 7.06 & 14.48 & 0.19 & 0.26 & 0.60 & $<\mathrm{Ld}$ \\
\hline 11 & 22.32 & 28.67 & 3.07 & 1.97 & 46.93 & 43.53 \\
\hline 12 & 23.80 & 26.45 & 5.74 & 7.45 & 49.43 & 24.88 \\
\hline Average & 14.76 & 21.00 & 2.25 & 2.52 & 24.56 & 17.10 \\
\hline Median & 10.43 & 17.11 & 0.47 & 0.44 & 2.28 & 1.98 \\
\hline Average & 12.88 & 18.19 & 2.59 & 1.93 & 10.33 & 6.93 \\
\hline Standart deviation & 7.41 & 6.8 & 3.12 & 2.66 & 17.81 & 13.38 \\
\hline Asymmetry & 0.45 & 0.10 & 0.70 & 1.44 & 2.00 & 2.41 \\
\hline Kurtosis & -1.39 & -1.14 & -1.51 & 0.79 & 2.50 & 5.35 \\
\hline
\end{tabular}

$<\mathrm{Ld}$ : Less than the detection limit. 
Table 5. Natural contents of $\mathrm{Ba}, \mathrm{Cr}$ and $\mathrm{Pb}$ in the surface (sup.) and subsurface (sub.) horizon of the main classes of soils in Southern Amazonas.

\begin{tabular}{|c|c|c|c|c|c|c|}
\hline \multirow{2}{*}{ Profile } & \multicolumn{2}{|c|}{$\mathrm{Ba}$} & \multicolumn{2}{|c|}{$\mathrm{Cr}$} & \multicolumn{2}{|c|}{$\mathrm{Pb}$} \\
\hline & Sup & Sub & Sup & Sub & Sup & Sub \\
\hline & \multicolumn{6}{|c|}{--------------------------------- $\mathrm{mg} \mathrm{kg}^{-1}$---------------------------- } \\
\hline & \multicolumn{6}{|c|}{ Field/Forest } \\
\hline 1 & 12.63 & 17.33 & 7.58 & 14.63 & 6.08 & 8.78 \\
\hline 2 & 33.78 & 21.88 & 8.33 & 12.35 & 14.28 & 12.10 \\
\hline 3 & 10.88 & 14.23 & 5.48 & 16.70 & 4.20 & 6.63 \\
\hline 4 & 26.00 & 22.65 & 6.60 & 6.13 & 6.85 & 6.60 \\
\hline \multirow[t]{2}{*}{ average } & 20.07 & 19.02 & 7.00 & 12.45 & 7.85 & 8.53 \\
\hline & \multicolumn{6}{|c|}{ Animated Relief } \\
\hline 5 & 3.03 & 1.68 & 33.50 & 24.45 & 6.95 & 5.05 \\
\hline 6 & 4.95 & 8.25 & 25.85 & 24.28 & 9.23 & 7.35 \\
\hline 7 & 4.03 & 5.73 & 9.08 & 9.23 & 8.45 & 9.70 \\
\hline 8 & 6.83 & 15.23 & 13.63 & 19.80 & 11.43 & 10.30 \\
\hline \multirow[t]{2}{*}{ Average } & 4.71 & 7.72 & 20.52 & 19.44 & 9.02 & 8.10 \\
\hline & \multicolumn{6}{|c|}{ Flooded/Non-Flooded } \\
\hline 9 & 8.75 & 8.40 & 5.20 & 13.73 & 2.55 & 2.68 \\
\hline 10 & 9.95 & 14.45 & 7.13 & 12.03 & 4.93 & 4.55 \\
\hline 11 & 150.45 & 55.48 & 17.15 & 19.15 & 20.18 & 19.33 \\
\hline 12 & 80.18 & 98.50 & 13.90 & 15.95 & 12.63 & 8.48 \\
\hline Average & 62.33 & 44.21 & 10.85 & 15.22 & 10.07 & 8.76 \\
\hline Median & 9.35 & 14.84 & 8.7 & 15.29 & 7.70 & 7.91 \\
\hline Average & 29.04 & 23.65 & 12.78 & 15.7 & 8.98 & 8.46 \\
\hline Standart deviation & 43.96 & 27.27 & 8.86 & 5.59 & 4.96 & 4.31 \\
\hline Asymmetry & 2.36 & 2.29 & 1.52 & 0.1 & 1.01 & 1.40 \\
\hline Kurtosis & 5.51 & 5.34 & 1.69 & -0.44 & 1.00 & 3.08 \\
\hline
\end{tabular}

In F/F and AR profiles (1, 2, 3, 4, 5, 6, 7 and 8$)$ and in the $\mathrm{F} / \mathrm{N}$ profiles ( 9 and 10 ), concentrations were lower than the detection limit (DL), corresponding to almost $83 \%$ of the profiles analyzed. Only in the environments $\mathrm{F} / \mathrm{F}$ (profile 2) and $\mathrm{F} / \mathrm{N}$ (profile 11 and 12) was the presence of Cd observed. However, even for these environments, the results were lower than the prevention value ( $\left.\mathrm{VP}=1.3 \mathrm{mg} \mathrm{kg}^{-1}\right)$ stated by CONAMA (2009), and are similar to the contents found in the States of Espírito Santo $(<0.13$ mg kg-1) (PAYE et al., 2010), São Paulo $(<0.5 \mathrm{mg}$ $\left.\mathrm{kg}^{-1}\right)$ (CETESB, 2001) and Paraíba (0.08 mg kg-1) (ALMEIDA JÚNIOR et al., 2016).
Besides the geomorphologic aspects conditioning the accumulation and maintenance of heavy metals in the $\mathrm{F} / \mathrm{N}$ environment, the Lithologic composition of the Argisols (Rondonianos Granite) is a determining factor in the elevated levels of Fe found in this environment. These soils, represented by profiles P11 and P12, are pedogenetically less evolved, as shown by the Ki ratio (1.37 and 1.26) (Table 2). Thus, this environment contains higher concentration and maintenance of $\mathrm{Fe}$ than the soils from other physiographic regions, because of its richness in Fe minerals, such as smectite, vermiculite, and biotite, which, when broken throughout time, release $\mathrm{Fe}$ into the soil. 
Contrastingly to the $\mathrm{F} / \mathrm{N}$ soils, the soils from the AR physiographic region are more weathered because of oxidizing conditions and free drainage (CAMPOS, 2009). In this case, the desilicatization $(\mathrm{Ki}=0.33$ to 0.77$)$ was intense, making residual minerals, such as $\mathrm{Fe}$ oxides, predominant (EMBRAPA, 2013); thus, explaining the high levels of Fe in the Latosol profiles 5 and 8. Yet the highest Fe levels, in the subsurface of the transitional $\mathrm{F} / \mathrm{F}$ regions, are attributed to the ferruginous concretions in the plinthic $\mathrm{P} 1$ profile (with plinthic characteristics); while in the $\mathrm{P} 2$ profile, to the reducing conditions $\left(\mathrm{Fe}^{+2}\right)$ of the environment. Still, all the Fe contents were higher in the subsurface, i.e. closer to the rock. The magnitude of the Fe contents in the southern region of Amazonas, found in this study, is in agreement with the results reported by Biondi et al. (2011), but much lower than those observed by Caires (2009).

The major abundance of Mn was found in the soils with elevated Fe content (profiles 11 and 12), especially in more weathered soils (profiles 6, 7 and 8), exhibiting the same geochemical behavior; i.e. they are constituents of ferromagnesian rock, as reported by Biondi et al. (2011). However, Mn contents reported here were much lower than were those of Fe and Mn ones quantified by Caires (2009) and Biondi et al. (2011).

Zinc levels were highest in superficial and subsurface horizons of $\mathrm{F} / \mathrm{N}$ soils, which presented 46.93 and $43.53 \mathrm{mg} \mathrm{kg}^{-1}$, respectively, for the Fluvisol (profile 11) (Table 4); followed by profile $12,49.43$ and $24.88 \mathrm{mg} \mathrm{kg}^{-1}$. In general, the $\mathrm{Zn}$ contents were inferior to other studies (SU; YANG, 2008; BIONDI et al., 2011; PRESTON et al., 2014; ALMEIDA JÚNIOR et al., 2016), confirming the low $\mathrm{Zn}$ supplying lithology potential in the southern region of Amazonas, as verified by the low contents in the subsurface horizons.

The highest levels of $\mathrm{Ba}$ were recorded in the $\mathrm{F} / \mathrm{N}$ and $\mathrm{F} / \mathrm{F}$ soils, possibly because of the incipient weathered soils from the flooded areas and the formation of $\mathrm{Mn}$ concretions and $\mathrm{Fe}$ oxyhydroxides with plinthic characteristics (KABATA-PENDIAS, 2010) (Table 5). In the AR soils, lower contents of $\mathrm{Ba}$ occurred due to the more intense weathering (Latosols and Argisols). In the $\mathrm{F} / \mathrm{N}$ areas, we noted an increase of $\mathrm{Ba}$ contents at the surface of profile $11\left(150 \mathrm{mg} \mathrm{kg}^{-1}\right)$, surpassing the results of VP (150 $\mathrm{mg} \mathrm{kg}{ }^{-1}$ ), established by CONAMA (2009) for the subsurface horizon (55.48 $\mathrm{mg} \mathrm{kg}^{-1}$ ). The disparity of results between the two horizons occurred due to surrounding sediment transportation (allochthonous), while the subsurface horizon reflected the material of origin (autochthonous).

The highest contents of $\mathrm{Cr}$ were found in the Highland region, Red Latosol (profile 5) and RedYellow Argisol (profile 6), having lower levels than most of the reference results from the rest of the Brazilian regions; e.g. São Paulo (40.0 $\mathrm{mg} \mathrm{kg}^{-1}$ ) (CETESB, 2001) and Espírito Santo (54.13 mg kg$\left.{ }^{1}\right)$ (PAYE et al., 2010).

Regarding $\mathrm{Pb}$ (Table 5), the highest results were observed in Fluvisols (profiles 11 and 12) and Haplic Gleysol (profile 2), which coincide with the elevated levels of Fe, because of its intense affinity with Fe oxides, forming more stable connections (KABATA-PENDIAS, 2010). In general, the soils presented no environmental contamination risks, since they contained lower $\mathrm{Pb}$ contents than the VP (72 $\mathrm{mg} \mathrm{kg}^{-1}$ ), as determined by CONAMA (2009). Comparing the levels of $\mathrm{Pb}$, it is possible to notice the similar averages of $\mathrm{Pb}$ content in Gleysol (7.08 $\mathrm{mg} \mathrm{kg}$ ), Neosol (14.64 $\mathrm{mg} \mathrm{kg}^{-1}$ ) and in Latosol (10.81 $\mathrm{mg} \mathrm{kg}^{-1}$ ) (PAYE et al., 2010).

The results obtained from the principal component analysis (PCA) showed different patterns in the soils of the physiographic regions (Table 6 and Figure 1). The variance quantity retained in the first two principal components was of $73.52 \%$ (53.18\% in CA1 and $20.34 \%$ in CA2). CA1 was characterized by a process involving the variables: $\mathrm{H}+\mathrm{Al}, \mathrm{CEC}, \mathrm{V} \%$, OC (organic carbon), sand, $\mathrm{Cu}, \mathrm{Co}, \mathrm{Cd}, \mathrm{Fe}, \mathrm{Zn}, \mathrm{Ba}$, and $\mathrm{Pb}$. Figure 1 
shows that the $\mathrm{F} / \mathrm{N}$ environment (profiles 11 and on the silt, clay, $\mathrm{Mn}$ and $\mathrm{Cr}$ variables were retained 12) was characterized by high values of $\mathrm{CEC}, \mathrm{V} \%$, in CA2. However, the soils with the highest sand $\mathrm{CO}, \mathrm{Ba}, \mathrm{Zn}, \mathrm{Cd}, \mathrm{Co}, \mathrm{Cu}, \mathrm{Pb}$ and $\mathrm{Fe}$ and low $\mathrm{pH}, \mathrm{Cr}$, contents were less associated to the heavy metal $\mathrm{Mn}$, clay, silt and sand results, while the information contents, when the latter presented no geochemical process.

Table 6. Correlation between each principal component, heavy metals and soil attributes in the surface and subsurface horizons of the physiographic regions Field/Forest, Animated Relief and Flooded/Non-Flooded in Southern Amazonas.

\begin{tabular}{ccc}
\hline Variables & CP1 & CP2 \\
\hline $\mathrm{pH}$ & -0.029868 & -0.073387 \\
$\mathrm{H}+\mathrm{Al}$ & -0.657594 & 0.611095 \\
$\mathrm{CEC}$ & -0.758349 & 0.547329 \\
$\mathrm{~V} \%$ & -0.788136 & -0.463869 \\
$\mathrm{OC}$ & -0.747092 & 0.277417 \\
$\mathrm{Sand}$ & 0.707093 & -0.336200 \\
$\mathrm{Silt}$ & -0.479792 & 0.810580 \\
$\mathrm{Clay}$ & -0.284924 & -0.770466 \\
$\mathrm{Cu}$ & -0.947069 & -0.147928 \\
$\mathrm{Co}$ & -0.933165 & -0.133600 \\
$\mathrm{Cd}$ & -0.967379 & 0.023406 \\
$\mathrm{Fe}$ & -0.818926 & -0.424537 \\
$\mathrm{Mn}$ & -0.423150 & -0.644193 \\
$\mathrm{Zn}$ & -0.977102 & 0.030389 \\
$\mathrm{Ba}$ & -0.961349 & 0.142645 \\
$\mathrm{Cr}$ & -0.207811 & -0.601706 \\
$\mathrm{~Pb}$ & -0.752758 & -0.322685 \\
\hline
\end{tabular}


Figure 1. Principal component analysis (PCA) based on soil variables in different physiographic of Southern of the state of Amazonas.

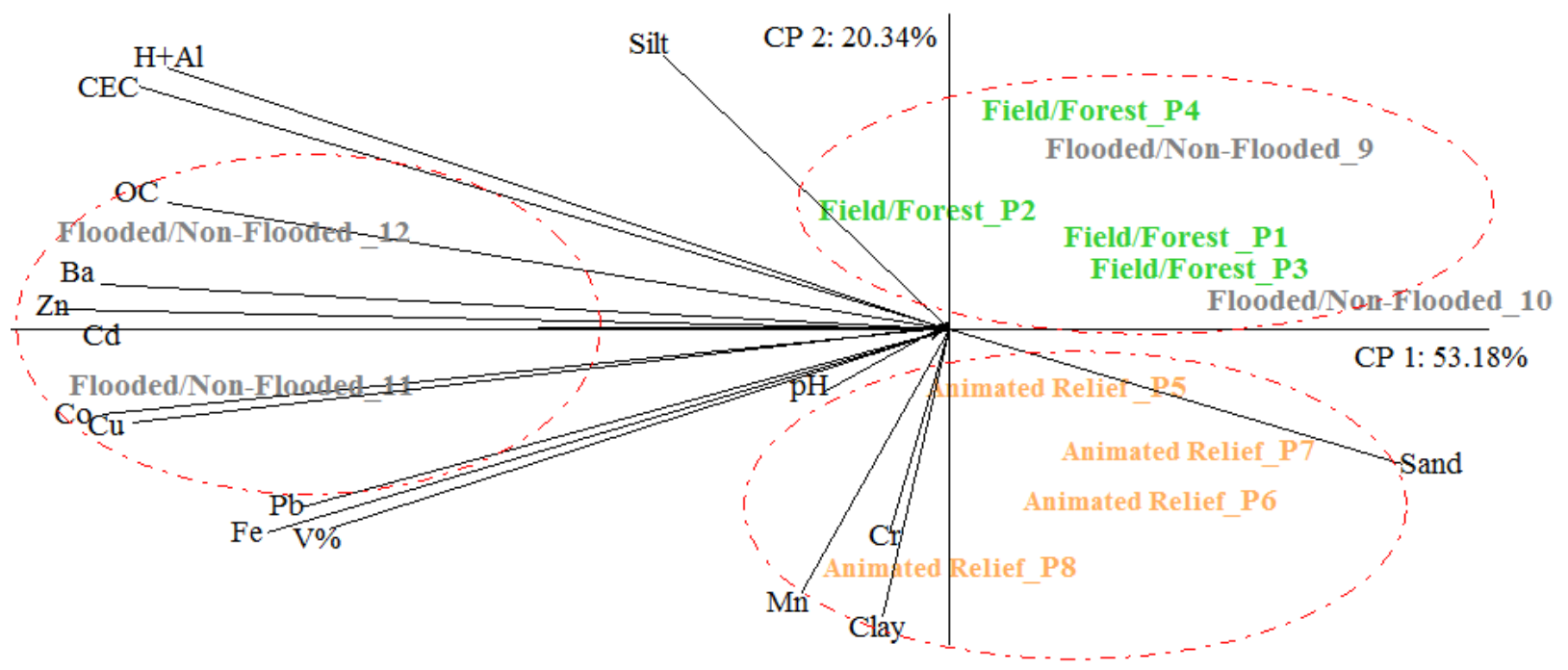

In profile 11 (Eutric Fluvisol) and in profile 12 (Fluvi-Eutric Gleysol) (Figure 1), chemically richer soils were observed, which can be confirmed by the CEC and $\mathrm{V} \%$ attributes. The highest values of organic $\mathrm{C}$ are due to the hydromorphic conditions of the soil in the flooded area, which slow down organic matter $(\mathrm{OM})$ decomposition. Thus, organic carboxylic and phenolic radicals release $\mathrm{H}^{+}$ (RANGEL; SILVA, 2007), which will compose the $\mathrm{CEC}$ and complex metals, such as $\mathrm{Fe}, \mathrm{Cd}, \mathrm{Ba}, \mathrm{Zn}$, $\mathrm{Co}, \mathrm{Cu}$ and $\mathrm{Pb}$ (LI et al., 2013).

The contents of $\mathrm{Cr}$ and $\mathrm{Mn}$ were strongly associated with the soils containing higher levels of clay, i.e. soils in advanced decomposition stages, especially in profile 8 , regarding the dystrophic Latosol. Yet, the other profiles $(5,6$, and 7$)$ of the AR pedological unit were differentiated because of the sand contents. On the other hand, none of the variables was capable of differentiating the profiles $1,2,3$, and 4 from the F/F pedological units, and profiles 9 and 10 physiography F/N. However, the proximity of these environments suggests transitional environments, possibly because of the seasonal effect, which consists of flooding during the rainy season and drying during the drought periods (CAMPOS, 2009).
Positive correlations (Table 7) were found for $\mathrm{Cu}$, which was the only element to establish correlation $(\mathrm{p}<0.01)$ with $\mathrm{Ba}(\mathrm{r}-0.85 ; \mathrm{r}=0.70, \mathrm{Cd}(\mathrm{r}=0.82 ; \mathrm{r}$ $=0.72), \mathrm{Zn}(\mathrm{r}=0.83 ; \mathrm{r}=0.93)$, Co $(\mathrm{r}=0.72 ; \mathrm{r}=$ $0.85)$ and $\mathrm{Pb}(\mathrm{r}=0.91 ; \mathrm{r}=0.67)$ for both horizons. These close relations $(r>67 \%)$ suggest a common association with Rondonianos Granite. Although the clay content presented no positive correlation in the subsurface horizon, this was the attribute that best correlated $(\mathrm{p}<0.01)$ in the superficial horizon with $\mathrm{Co}(\mathrm{r}=0.64), \mathrm{Pb}(\mathrm{r}=0.68)$ and $\mathrm{Mn}(\mathrm{r}=0.58)$. As highlighted by Li et al. (2013), higher contents of clay elevate the $\mathrm{CEC}$, and the $\mathrm{Fe}$ and $\mathrm{Al}$ contents, maximizing adsorption of heavy metals in the sorption complex.

The Fe and clay contents in the superficial horizon $(r=0.62)$ showed significant correlation, indicating predominance of this metal in soils containing higher clay content. Additionally, they were concentrated especially in the forms of clay minerals and $\mathrm{Fe}$ oxides of the most weathered soils (Latosol and Argisol). Fe positively and significantly correlated $(\mathrm{p}<0.01$ and $\mathrm{p}<0.05)$ to $\mathrm{Cr}(\mathrm{r}=0.77)$ at the surface, while correlating to $\mathrm{Ba}(\mathrm{r}=0.60), \mathrm{Cu}(\mathrm{r}$ $=0.64)$ and $\mathrm{Pb}(\mathrm{r}=0.61)$ at the subsurface, and in both horizons to $\mathrm{Co}(\mathrm{r}=0.71 ; \mathrm{r}=0.65)$ and $\mathrm{Zn}(\mathrm{r}=$ $0.61 ; \mathrm{r}=0.64)$. 
Table 7. Pearson correlation coefficients among the metal contents in reference soils of Southern Amazonas.

\begin{tabular}{|c|c|c|c|c|c|c|c|c|c|c|}
\hline \multicolumn{11}{|c|}{ Surface } \\
\hline & $\mathrm{Ba}$ & $\mathrm{Cd}$ & $\mathrm{Co}$ & $\mathrm{Zn}$ & $\mathrm{Cu}$ & $\mathrm{Pb}$ & $\mathrm{Cr}$ & $\mathrm{Fe}$ & $\mathrm{Mn}$ & $\mathrm{Al}$ \\
\hline $\mathrm{Cd}$ & $0.98 * *$ & & & & & & & & & \\
\hline Co & $0.77 * *$ & $0.73 * *$ & & & & & & & & \\
\hline $\mathrm{Zn}$ & $0.92 * *$ & $0.86^{* *}$ & $0.91 * *$ & & & & & & & \\
\hline $\mathrm{Cu}$ & $0.85 * *$ & $0.82 * *$ & $0.72 * *$ & $0.83 * *$ & & & & & & \\
\hline $\mathrm{Pb}$ & $0.81 * *$ & $0.81 * *$ & $0.72 * *$ & $0.73 * *$ & $0.91 * *$ & & & & & \\
\hline $\mathrm{Cr}$ & $0.07^{\mathrm{ns}}$ & $0.15^{\text {ns }}$ & $0.18^{\mathrm{ns}}$ & $0.13^{\text {ns }}$ & $0.20^{\text {ns }}$ & $0.27^{\mathrm{ns}}$ & & & & \\
\hline $\mathrm{Fe}$ & $0.48^{\mathrm{ns}}$ & $0.50^{\text {ns }}$ & $0.71 * *$ & $0.61^{*}$ & $0.46^{\mathrm{ns}}$ & $0.50^{\text {ns }}$ & $0.77 * *$ & & & \\
\hline $\mathrm{Mn}$ & $0.10^{\mathrm{ns}}$ & $0.12^{\mathrm{ns}}$ & $0.59 * *$ & $0.25^{\mathrm{ns}}$ & $0.18^{\mathrm{ns}}$ & $0.41^{\mathrm{ns}}$ & $0.34^{\mathrm{ns}}$ & $0.55^{\mathrm{ns}}$ & & \\
\hline $\mathrm{Al}$ & $0.10^{\mathrm{ns}}$ & $0.16^{\mathrm{ns}}$ & $0.04^{\mathrm{ns}}$ & $0.13^{\mathrm{ns}}$ & $0.30^{\mathrm{ns}}$ & $0.25^{\mathrm{ns}}$ & $0.85^{* *}$ & $0.63 *$ & $-0.02^{\mathrm{ns}}$ & \\
\hline $\mathrm{pH}$ & $-0.06^{\mathrm{ns}}$ & $-0.14^{\mathrm{ns}}$ & $-0.16^{\mathrm{ns}}$ & $-0.08^{\mathrm{ns}}$ & $0.00^{\text {ns }}$ & $0.14^{\mathrm{ns}}$ & $0.13^{\text {ns }}$ & $-0.08^{\mathrm{ns}}$ & $-0.04^{\mathrm{ns}}$ & $0.11^{\mathrm{ns}}$ \\
\hline $\mathrm{OM}$ & $-0.43^{\mathrm{ns}}$ & $-0.42^{\mathrm{ns}}$ & $-0.51^{\mathrm{ns}}$ & $-0.46^{\mathrm{ns}}$ & $-0.10^{\mathrm{ns}}$ & $-0.06^{\mathrm{ns}}$ & $0.42^{\mathrm{ns}}$ & $-0.04^{\mathrm{ns}}$ & $-0.20^{\mathrm{ns}}$ & $0.61^{*}$ \\
\hline Clay & $0.47^{\mathrm{ns}}$ & $0.52^{\mathrm{ns}}$ & $0.64^{*}$ & $0.46^{\mathrm{ns}}$ & $0.55^{\text {ns }}$ & $0.68 *$ & $0.35^{\mathrm{ns}}$ & $0.62 *$ & $0.58^{*}$ & $0.24^{\text {ns }}$ \\
\hline \multicolumn{11}{|c|}{ Subsurface } \\
\hline & $\mathrm{Ba}$ & $\mathrm{Cd}$ & $\mathrm{Co}$ & $\mathrm{Zn}$ & $\mathrm{Cu}$ & $\mathrm{Pb}$ & $\mathrm{Cr}$ & $\mathrm{Fe}$ & $\mathrm{Mn}$ & $\mathrm{Al}$ \\
\hline $\mathrm{Cd}$ & $0.97 * *$ & & & & & & & & & \\
\hline Co & $0.93 * *$ & $0.94 *$ & & & & & & & & \\
\hline $\mathrm{Zn}$ & $0.78 * *$ & $0.74 *$ & $0.86^{* *}$ & & & & & & & \\
\hline $\mathrm{Cu}$ & $0.70 * *$ & $0.72 *$ & $0.85 * *$ & $0.93 * *$ & & & & & & \\
\hline $\mathrm{Pb}$ & $0.41^{\mathrm{ns}}$ & $0.31^{\mathrm{ns}}$ & $0.54^{\mathrm{ns}}$ & $0.76^{* *}$ & $0.67 *$ & & & & & \\
\hline $\mathrm{Cr}$ & $-0.02^{\mathrm{ns}}$ & $0.09^{\text {ns }}$ & $0.10^{\text {ns }}$ & $0.17^{\mathrm{ns}}$ & $0.35^{\text {ns }}$ & $0.10^{\mathrm{ns}}$ & & & & \\
\hline $\mathrm{Fe}$ & $0.60 *$ & $0.55^{\mathrm{ns}}$ & $0.65^{*}$ & $0.64 *$ & $0.64 *$ & $0.61^{*}$ & $0.36^{\mathrm{ns}}$ & & & \\
\hline $\mathrm{Mn}$ & $0.56^{\mathrm{ns}}$ & $0.63^{*}$ & $0.70^{*}$ & $0.36^{\mathrm{ns}}$ & $0.54^{\mathrm{ns}}$ & $0.25^{\mathrm{ns}}$ & $0.17^{\mathrm{ns}}$ & $0.48^{\mathrm{ns}}$ & & \\
\hline $\mathrm{Al}$ & $0.04^{\mathrm{ns}}$ & $0.19^{\text {ns }}$ & $0.20^{\mathrm{ns}}$ & $0.25^{\mathrm{ns}}$ & $0.53^{\mathrm{ns}}$ & $0.09^{\text {ns }}$ & $0.81 * *$ & $0.17^{\mathrm{ns}}$ & $0.25^{\mathrm{ns}}$ & \\
\hline $\mathrm{pH}$ & $-0.1^{\mathrm{ns}}$ & $-0.02^{\mathrm{ns}}$ & $-0.02^{\mathrm{ns}}$ & $-0.06^{\mathrm{ns}}$ & $0.04^{\mathrm{ns}}$ & $0.16^{\mathrm{ns}}$ & $0.57^{\mathrm{ns}}$ & $0.48^{\text {ns }}$ & $0.10^{\text {ns }}$ & $0.37^{\text {ns }}$ \\
\hline $\mathrm{OM}$ & $-0.11^{\mathrm{ns}}$ & $-0.08^{\mathrm{ns}}$ & $-0.07^{\mathrm{ns}}$ & $-0.20^{\mathrm{ns}}$ & $-0.17^{\mathrm{ns}}$ & $-0.03^{\text {ns }}$ & $0.45^{\mathrm{ns}}$ & $-0.10^{\mathrm{ns}}$ & $0.21^{\mathrm{ns}}$ & $0.13^{\text {ns }}$ \\
\hline Clay & $-0.3^{\mathrm{ns}}$ & $-0.35^{\text {ns }}$ & $-0.22^{\mathrm{ns}}$ & $-0.08^{\text {ns }}$ & $0.00^{\mathrm{ns}}$ & $0.37^{\text {ns }}$ & $0.27^{\mathrm{ns}}$ & $-0.15^{\text {ns }}$ & $0.01^{\mathrm{ns}}$ & $0.31^{\text {ns }}$ \\
\hline
\end{tabular}

** Significant at $1 \%(\mathrm{p}<0.01) ; *$ Significant at $5 \%(\mathrm{p}<0.05)$; ns: not significant.

In compliance with Araújo et al. (2002), this is due to its strong affinity to $\mathrm{OH}^{-}$radicals, in the surface of the Fe oxides, and, on the other hand, is less correlated to humic substances, as revealed by the negative correlations between $\mathrm{OM}$ and $\mathrm{Ba}, \mathrm{Cd}$, $\mathrm{Co}, \mathrm{Zn}, \mathrm{Cu}, \mathrm{Pb}, \mathrm{Cr}$, and $\mathrm{Mn}$. This behavior shows that the contents of $\mathrm{Ba}, \mathrm{Cd}, \mathrm{Co}, \mathrm{Cr}, \mathrm{Cu}, \mathrm{Fe}, \mathrm{Mn}, \mathrm{Pb}$, and $\mathrm{Zn}$ in soils from the southern Amazonas state are of natural origin, as a large part of these metals is associated with the inorganic fraction of the soil.

\section{Conclusions}

The results reported in this study indicate that soils of the southern Amazonas state have a low potential of supplying heavy metals. The contents of these elements found are in the following decreasing order: $\mathrm{Ba}>\mathrm{Fe}>\mathrm{Cr}>\mathrm{Pb}>\mathrm{Zn}>\mathrm{Cu}>\mathrm{Mn}>\mathrm{Co}>\mathrm{Cd}$.

The natural contents of heavy metals vary depending on the soil type, weathering level and, physiographic regions, being similar or inferior to the contents found in other Brazilian regions. For most of the evaluated metals, Neosols presented the highest natural contents, while Cambisols showed the lowest ones. 


\section{References}

AGENCY FOR TOXIC SUBSTANCES AND DISEASE REGISTRY - ATSDR. Toxicological profile for cadmium. Atlanta: U. S. Department of Public Health and Human Services, Public Health Service, 2012. 487 p.

ALMEIDA JÚNIOR, A. B.; NASCIMENTO, C. W. A.; BIONDI, C. M.; SOUZA, A. P.; BARROS, F. M. R. Background and reference values of metals in soils from ParaíbaState, Brazil. Revista Brasileirade Ciênciado Solo, Viçosa, MG, v. 40, n. e0150122, p. 1-13, 2016. Available at: $<$ http://www.scielo.br/scielo. php?script=sci_arttext\& $\mathrm{pid}=\mathrm{S} 0100-06832016000100509>$. Accessed at: $28 \mathrm{dec}$. 2016.

ALVARES, C. A.; STAPE, J. L.; SENTELHAS, P. C.; GONÇALVES, J. L. M.; SPAROVEK, G. Koppen's climate classification map for Brazil. Meteorologische Zeitschrift, Stuttgart, v. 22, n. 6, p. 711-728, 2014. Available at: <http://www.lerf.eco.br/img/publicacoes/ Alvares_etal_2014.pdf $>$. Accessed at: 6 may 2017.

ARAÚJO, W. S.; AMARAL SOBRINHO, N. M. B.; MAZUR, N.; GOMES, P. C. Relação entre adsorção de metais pesados e atributos químicos e físicos de classes de solo. Revista Brasileira de Ciência do Solo, Viçosa, MG, v. 26, n. 1, p. 17-27, 2002. Disponível em: $\quad<$ http://www.scielo.br/scielo.php?pid=S0100$06832002000100003 \&$ script $=$ sci_abstract\&tlng $=\mathrm{pt}>$. Acesso em: 22 nov. 2016.

BAIZE, D.; STERCKEMAN, T. Of the necessity of knowledge of the natural pedo-geochemical background content in the evaluation of the contamination of soils by trace elements. Science of The Total Environment, v. $264, \mathrm{n} \mathrm{1-2,}$ p. 127-139, 2001. Available at: $<$ http://www.sciencedirect.com/science/article/ pii/ S004896970000615X>. Accessed at: 7 may 2017.

BRASIL. Ministério das Minas e Energia. Projeto Radambrasil - folha SB. 20, Rio de Janeiro: Purus, 1978. p. 561.

BIONDI, C. M.; NASCIMENTO, C. W. A.; FABRICIO NETA, A. B. Teores naturais de bário em solos de referência do estado de Pernambuco. Revista Brasileira de Ciência do Solo, Viçosa, MG, v. 35, n. 5, p. 1819-1826, 2011a. Disponível em: <http:// www.scielo.br/scielo.php?script $=$ sci_arttext\&pid $=$ S0100-06832011000500036 $>$. Acesso em: 22 nov. 2016.

BIONDI, C. M.; NASCIMENTO, C. W. A; FABRICIO NETA, A. B.; RIBEIRO, M. R. Concentrations of Fe, Mn, $\mathrm{Zn}, \mathrm{Cu}, \mathrm{Ni}$ and $\mathrm{Co}$ in benchmark soils of Pernambuco, Brazil. Revista Brasileira de Ciência do Solo, Viçosa, MG, v. 35, n. 3, p. 1057-1066, 2011b. Disponível em:
$<$ http://www.scielo.br/scielo.php?script=sci_ arttext\&p id $=$ S0100-06832011000300039 $>$. Acesso em: 22 nov. 2016.

CAIRES, S. M. Determinação dos teores naturais de metais pesados em solos do Estado de Minas Gerais como subsídio ao estabelecimento de valores de referência de qualidade $(M G)$. 2009. Tese (Doutorado em Solos e Nutrição de Plantas) - Universidade Federal de Viçosa, Viçosa.

CAMPOS, M. C. C. Pedogeomorfologia aplicada à ambientes amazônicos do médio Rio Madeira (AM). 2009. Tese (Doutorado em Ciência da Solo) - Universidade Federal Rural de Pernambuco, Recife.

COMPANHIA DE TECNOLOGIA DE SANEAMENTO AMBIENTAL - CETESB. Relatório de estabelecimento de valores orientadores para solos e águas subterrâneas no Estado de São Paulo. São Paulo: CETESB; 2001. 247 p.

CONSELHO NACIONAL DO MEIO AMBIENTE - CONAMA. Resolução $n^{\circ} 420$, de 28 de dezembro de 2009. Dispõe sobre critérios e valores orientadores de qualidade do solo quanto à presença de substâncias químicas e estabelece diretrizes para o gerenciamento ambiental de áreas contaminadas por essas substâncias em decorrência de atividades antrópicas. Brasília: DCONAMA, 2009. Disponível em: <http://www.mma. gov.br/port/conama/res/res09/res42009.pdf>. Acesso em: 12 nov. 2016.

EMPRESA BRASILEIRA DE PESQUISA AGROPECUÁRIA - EMBRAPA. Manual de métodos de análise de solo. 3. ed. Rio de Janeiro: Embrapa Solos, 2011. $212 \mathrm{p}$.

. Sistema brasileiro de classificação de solos. 3 . ed. Brasília: Embrapa, 2013. 353 p.

HAIR, J. F.; ANDERSON, R. E.; TATHAM, R. L.; BLACK, W. Análise multivariada de dados. 5. ed. Porto Alegre: Bookman, 2005. 593 p.

KABATA-PENDIAS, A. Trace elements in soils and plants. $4^{\text {th }}$ ed. Boca Raton: CRC Press, 2010. 548 p.

KAISER, H. F. The varimax criterion for analytic rotation in factor analysis. Psychometrika, New York, v. 23, n. 3, p. 187-200, 1958. Available at: < http://link.springer. com/article/10.1007/BF02289233>. Accessed at: 11 nov. 2016.

LI, L.; XING, W.; SCHECKEL, K. G.; XIANG, G.; JI, H.; LI, H. Lead retention in a calcareous soil influenced by calcium and phosphate amendments. Journal of Hazardous Materials, Amsterdam, v. 262, n. 15, p. 250255, 2013. Available at: <https://www.ncbi.nlm.nih.gov/ pubmed/24036148>. Accessed at: 27 nov. 2016. 
MACEDO, F. G.; MELO, W. J.; MERLINO, L. C. S.; RIBEIRO, M. H.; MELO, G. M. P.; CAMACHO, M. A. Acúmulo e disponibilidade de cromo, cádmio e chumbo em solos tratados com lodo de esgoto por onze anos consecutivos. Semina: Ciências Agrárias, Londrina, v. 33, n. 1, p. 101-114, 2012. Disponível em: <http://www. redalyc.org/articulo.oa? $\mathrm{id}=445744111010>$. Acesso em: 12 ago. 2017.

MECHI, A.; SANCHES, D. L. Impactos ambientais da mineração no Estado de São Paulo. Estudos Avançados, São Paulo, v. 24, n. 68, p. 209-220, 2010. Disponível em: $<$ http://www.scielo.br/scielo.php? script=sci_arttext\& pid=S0103-40142010000100016>. Acesso em: 7 maio 2017.

NG, C.C.; RAHMAN, M. M.; BOYCE, A. N.; ABAS, M. R. Heavy metals phyto-assessment in commonly grown vegetables: water spinach (I. aquatica) and okra (A. esculentus). Springer Plus, Heidelberg, v. 5, n. 1, p. 469-477, 2016. Available at: <https://www.ncbi.nlm. nih.gov/pmc/articles/PMC4833764/pdf/40064_2016 Article_2125.pdf $>$. Accessed at: 7 may 2017.

PAYE, H. S.; MELlO, J. W. V.; ABRAHÃO, W. A. P.; FERNANDES FILHO, E. I.; DIAS, L. C. P.; CASTRO, M. L.O.;MELO, S.B.;FRANÇA, M.M. Valores de referência de qualidade para metais pesados em solos no estado do Espírito Santo. Revista Brasileira de Ciência do Solo, Viçosa, MG, v. 34, n. 6, p. 2041-2051, 2010. Disponível em: $<$ http://www.scielo.br/scielo.php?script=sci_arttext \&pid=S0100-06832010000600028>. Acesso em: 26 nov. 2016.

PRESTON, W.; NASCIMENTO, C. W. A.; BIONDI, C. M.; SOUZA JUNIOR, V. S.; SILVA, W. R.; FERREIRA, H. A. Valores de referência de qualidade para metais pesados em solos do Rio Grande do Norte. Revista Brasileira de Ciência do Solo, Viçosa, MG, v. 38, n. 3, p. 2041-2051, 2014. Disponível em: <http:// www.scielo.br/scielo.php?script $=$ sci_arttext\&pid $=\mathrm{S} 0100-06832014000300035>$. Acesso em: 25 nov. 2016.
RANGEL, O. J. P.; SILVA, C. A. Estoques de carbono e nitrogênio e frações orgânicas de Latossolo submetido a diferentes sistemas de uso e manejo. Revista Brasileira de Ciência do Solo, Viçosa, MG, v. 31, n. 6, p. 1609-1623, 2007. Disponível em: <http:// www.scielo.br/scielo.php?script $=$ sci_arttext\&pid $=\mathrm{S} 0100-06832007000600037 \mathrm{\gamma}$. Acesso em: 29 nov. 2016.

SILVA, L. S.; GALINDO, I. C. L.; NASCIMENTO, C. W. A.; GOMES, R. P.; CAMPOS, M. C. C.; FREITAS, L.; OLIVEIRA, I. A. Heavy metal contents in Latosols cultivated with vegetable crops. Pesquisa Agropecuária Tropical, Goiânia, v. 46, n. 4, p. 391-400, 2016. Available at: <http://www.scielo.br/scielo. php?script=sci arttext\&pid=S1983-40632016000400391\&lng=en\&nrm $=$ iso $>$. Accessed at: 30 nov. 2016.

STATISTICA SOFTWARE - STATSOFT. Statistica 7.0, EUA Software. Tucksa: StatSoft, 2008.

SU, Y.; YANG, R. Background concentrations of elements in surface soils and their changes as affected by agriculture use in the desert-oasis ecotone in the middle of Heihe River Basin, North-west China. Journal Geochemical Exploration, Amsterdam, v. 98, n. 3, p. 5764, 2008. Available at: <http://www.sciencedirect. com/ science/article/pii/S0375674208000046>. Accessed at: 30 nov. 2016.

UNITED STATES ENVIRONMENTAL PROTECTION AGENCY - USEPA. Method 3051a: microwave assisted acid digestion of sediments. Washington: Government Printing Office, 1998. 
